\title{
Individual Investors and the Financial Crisis*
}

\author{
Jarl Kallberg \\ Washington State University
}

Crocker H. Liu

Cornell University

Na Wang

Hofstra University

\footnotetext{
${ }^{*}$ We are grateful to Ilona Babenka, Stephen J. Brown, David Hirshleifer, Adam Nowak and Yuri Tserlukevich for helpful comments, and seminar participants at the 2010 Financial Management Association annual meeting, 2012 Academy of Behavioral Finance \& Economics annual meeting, 2013 Eastern Financial Association annual meeting, Arizona State University, Bank of America, and Hofstra University. Jarl Kallberg, College of Business, Washington State University, jarl.kallberg@wsu.edu, 509335-3797. Crocker H. Liu, School of Hotel Administration, Cornell University. Ithaca, NY 14853. Email: chl62@ cornell.edu. Phone: 607-255-3739. Fax: 607-255-1277. Na Wang, Frank G. Zarb School of Business, Hofstra University, Hempstead, NY 11549, na.wang@ hofstra.edu, 516-463-5498. All errors are our own.
} 


\begin{abstract}
This paper studies the trading behavior of individual Chinese investors before and during the recent financial crisis. We have three major findings: (i) individual investors did not withdraw their capital from the equity market during the crisis; instead, they reduced investment more in the pre-crisis period, especially following portfolio gains; (ii) the net flow decisions were influenced by past positive returns, but not by past losses; the net flow patterns were consistent with the disposition effect, which was even stronger during the crisis; (iii) during the crisis, investors revised their portfolios to hold relatively safer and more liquid stocks, and this pattern is more evident for small investors.

Key words: individual investors, financial crisis, net flows, disposition effect, portfolio holdings.

JEL Classification: G01, G11, G15.
\end{abstract}




\section{Introduction}

The global financial crisis was an unprecedented shock to financial markets. In the period from November 2007 to December 2008, world equity markets lost $\$ 32.2$ trillion, more than half of the initial value. Figure 1 shows this decline in global equity market capitalization over the period December 2006 to November 2009. The extent of the crisis was unlike anything investors had previously faced. This new environment created a unique opportunity to analyze the behavior of individual investors in unfamiliar and highly disconcerting circumstances.

The purpose of this study is to empirically examine the behavior of individual investors before and during the crisis in terms of their investment cash flows and revisions to their stock portfolios. We use data prior to the crisis to benchmark the key characteristics of our sample and we then investigate how these characteristics changed during the crisis period. We further examine how factors such as investment size (our proxy for wealth), behavioral biases, past returns, gender and age influence investor investment decisions.

Our analysis is based on individual investor trading data from a random sample of 15,040 Chinese investors over the period from January 2005 to November 2008. As Figure 2 shows, the Chinese stock market experienced a huge decline starting in October 2007. The Shanghai Stock Exchange A-share Index fell from its highest monthly level of 5,955 to 1,871 by the end of our sample period. This period coincides with the decline of the global equity market capitalization as depicted in Figure 1. Investors in the Chinese stock markets, in aggregate, lost $68.4 \%$ of their investment: a loss of about $\$ 3$ trillion over 13 months.

Analyzing the behavior of individual Chinese investors offers several important advantages. Since margin trading and short selling were not allowed in the Chinese stock markets during our sample period, individual investors could hold long positions only and did not need to sell to meet margin requirements. ${ }^{1}$ More importantly, individual investors in China

\footnotetext{
${ }^{1}$ Margin trading and short selling were not allowed in the Chinese stock market until March 31, 2010.
} 
do not pay capital gains taxes on stock market investment income. ${ }^{2}$ The absence of taxdriven trading removes a major obstacle in the attempt to identify motives for trade. ${ }^{3}$ Thus, a distinctive feature of our study is that it controls for the confounding effects of transactions motivated by taxes, short positions or margin requirements.

Our focus on the investment behavior of individual investors in both a rising and subsequently declining stock market is another feature of our study. ${ }^{4}$ Most studies of individual investors are conducted in a period of generally rising markets. For example, Odean (1999), Grinblatt and Keloharju (2000) and Barber and Odean (2001) study individual investors in the bull markets of the 1990s. ${ }^{5}$ We expect that individual investors will behave differently in a falling market, especially when the losses are of such a staggering magnitude.

We partition our sample into a pre-crisis and a crisis period. We use the first subperiod to create a benchmark in order to address our key research question: How did investor behavior change over the crisis period? We measure this change along several dimensions. First, we look at investor cash flows in each period. How individual investors adjust their equity holdings during market downturns is a relatively less explored question in comparison to numerous studies of the behavior of institutional and foreign investors. For example, Choe, Kho and Stulz (1999), Kim and Wei (2002) and Karolyi (2002) study the trading behavior of foreign investors during the Asian financial crisis. They find that foreign investors are net sellers, and are more likely to engage in positive feedback trading strategies and herding than domestic investors. Brunnermeier and Nagel (2004) document the trading behavior of institutional investors during the technology bubble. They show that hedge fund managers did not provide a correcting force on stock prices, instead they invested heavily in technology stocks before the bubble burst and reduced their positions in stocks

\footnotetext{
${ }^{2}$ China does have a $20 \%$ capital gains tax on real estate investments.

${ }^{3}$ For example, Kaustia (2010), using a sample of Finnish investors, finds little support for prospect theory, instead he shows the importance of selling to achieve zero capital gains.

${ }^{4}$ The papers that analyze investor behavior during the crisis are reviewed later in this section.

${ }^{5}$ Odean (1999) and Barber and Odean (2001) study U.S. individual trading behavior from January 1987 through December 1993 and from February 1991 through January 1997, respectively. Grinblatt and Keloharju (2000) use Finnish data from January 1995 through December 1996.
} 
that subsequently declined. Ben-David, Franzoni and Moussawi (2012) show that hedge funds sold significant portions of their equity holdings during the recent financial crisis and that these selloffs occurred in more liquid stocks. Mutual funds also withdrew their capital in response to poor returns, but not as severely as hedge funds.

The few current studies of individual investors over the crisis period provide divergent conclusions. Dorn and Weber (2013) in their sample of German investors document that investors in active mutual funds were more likely to reduce their overall equity exposure during the crisis, despite the negative tax impact. ${ }^{6}$ Hoffman, Post and Pennings (2013) use a sample of 1,376 Dutch investors to link investors' portfolio decisions with their responses to a survey addressing their expectations and risk attitudes. They conclude (page 72): Individual investors also do not try to reduce risk by shifting from risky investments to cash. Instead, individual investors use the depressed asset prices as a chance to enter the stock market. Given these conflicting results, the first hypothesis we examine is whether or not investors' capital infusions and withdrawals have different patterns in the pre-crisis and crisis periods.

Second, there is significant evidence that investors react differently to past gains versus losses; for example, Kahneman and Tversky (1979); Thaler and Johnson (1990); Barberis and Huang (2001); Barberis, Huang and Santos (2001). We examine, in particular, the disposition effect: the tendency of investors to liquidate better performing stocks, "winners," and to hold onto underperforming stocks, "losers."7 While this behavior has been well documented in many global markets, ${ }^{8}$ its dynamics during a crisis have not been studied. Szyszka (2010) postulates that the disposition effect gave way to a "panic effect" during the financial crisis. This hypothesis is not empirically investigated, but he notes that the scale and pace of price drops are consistent with this proposition. As a consequence of higher risk aversion and fear, investors sell losers, exacerbating the downward spiral in prices.

\footnotetext{
${ }^{6}$ Their analysis is quite different than ours in that its major focus is on the shifting of investor cash among different types of funds and on the influence of changes in German capital gains taxes.

${ }^{7}$ Shefrin and Statman (1985); Odean (1998); Barberis and Xiong (2009).

${ }^{8}$ I.a., Kim and Nofsinger (2007, 2008); Barber, Lee, Liu and Odean (2007).
} 
On the other hand, it is plausible that during a crisis these types of investor "biases" are exaggerated. For example, with respect to the disposition effect, the prediction would be that investors were even more likely to sell winners rather than losers. This observation would be consistent with the literature in psychology showing that, under stress, individuals make poorer decisions. ${ }^{9}$ Based on these contrasting views, our second hypothesis is whether the disposition effect changes significantly in the crisis period.

Third, we examine the nature of portfolio revisions. Recent studies that have analyzed the investment portfolios of individual investors during the crisis period include Dorn and Weber (2013). They examine a sample of 40,000 German individual investors from 2007 to 201 and show that, over the crisis period, equity portfolio diversification worsens; specifically, they find a shift towards stocks that have a larger market capitalization, higher idiosyncratic volatility and lower past returns. Guiso, Sapienza and Zingales (2013) use a survey of Italian investors to show that investors' risk aversion increased following the financial crisis. ${ }^{10}$

Portfolio revision is naturally related to the research analyzing a flight to quality and/or liquidity within the equity market during the crisis. In other words, do investors rebalance their portfolios towards less risky and more liquid stocks? Several papers have documented a flight to quality during a crisis such as the Asian crisis of 1997 and the Russian crisis of 1998. ${ }^{11}$ Beber, Brandt and Kavejecz (2009) analyze flight to quality and liquidity in the Euro bond market. While the flight to liquidity literature typically analyzes the stock-bond return relation, for example, Goyenko and Ukhov (2009), other studies show that investors shift towards more liquid stocks during a crisis; one example is Amihud, Mendelson and Wood (1990). In a related article, Scholes (2000) observes that during a crisis, investors unwind their portfolios by selling the most liquid securities first.

\footnotetext{
${ }^{9}$ There is an extensive literature that deals with these issues, often under the rubric of "risk as feelings;" examples include Loewenstein (2000); Loewenstein, Weber, Hsee and Welch (2001); Slovic, Finucane, Peters and MacGregor (2004). Further, Lo, Repin and Steenbarger (2005) document that traders with more intense reactions to gains and losses had significantly worse performance.

${ }^{10}$ Further, using an experimental setting, they show that their participants' risk aversion increased after observing a scary movie.

${ }^{11}$ For example, Choe, Kho and Stulz (1999).
} 
A related aspect of individual investment behavior is developed in Dorn and Huberman (2005). They use a sample of 20,000 German individual investors from 1995 to 2000 to provide support for what they dub the preferred risk habitat: individuals do not view securities in a portfolio context, rather they tend to select stocks independently based on the level of risk that they are comfortable with; thus focusing on stocks with a specific "target" volatility. Hence, the third hypothesis to be addressed is whether or not investors' portfolio risk and characteristics changed from the pre-crisis to the crisis period.

Finally, several studies have established relations between investor characteristics such as gender, age or investment size and investment behavior. ${ }^{12}$ Our data allow us to focus on how these factors influence the decision to withdraw or invest capital during both the precrisis and crisis periods, and to further investigate the link between investor characteristics and portfolio revisions during the crisis. Evidence exists that large individual investors do not trade like small investors. For example, Giannetti and Simonov (2006) argue that large individual investors are the only type of investors who are not attracted to more liquid and larger capitalization stocks. We would therefore expect large investors to hold riskier stocks than small investors and to be less prone to exhibit behavioral biases. Vissing-Jorgensen (2004) observes: (page 178): In sum, the evidence suggests that most of the seeming irrational investor behaviors are weaker for investors with higher wealth or income (frequent trading of directly held stocks being the main exception). We specifically examine how individual investor characteristics influence the nature of the trading behavior in terms of the previous three hypotheses.

To briefly review our major results, with respect to our first hypothesis, in contrast to Scholes (2000) and Dorn and Weber (2013), we find that individual investors, in aggregate, increased their equity investment during the crisis, especially during the first half. Furthermore, the proportional net flow is negatively related (significant at the $1 \%$ level) to positive past returns, but has an insignificant relation with negative past returns. The asymmetric

\footnotetext{
${ }^{12}$ For example, Barber and Odean (2001).
} 
relation between net flows and past portfolio returns is consistent with the prediction of the disposition effect. Following the approach of Odean (1998) and Barber, Lee, Liu and Odean (2007), we find that the disposition effect was present over the entire sample period. In the pre-crisis period the percentage of gains realized (PGR) was $23.5 \%$, which is significantly larger than the percentage of losses realized (PLR) of 19.6\%. However, in the crisis period, PGR and PLR both declined significantly, with PGR falling by $3.0 \%$ and PLR falling by 6.6\%. Thus, the disposition effect was even stronger during the crisis period, providing evidence for our second hypothesis. Both large and small investors exhibit the disposition effect. However, large investors demonstrated a lower tendency to display the disposition effect than small investors; this difference was significant over all sample periods. ${ }^{13}$

With regard to the investor's portfolio revisions during the crisis period addressed in the third hypothesis, we show that individual investors tended to shift to less risky and more liquid stocks. Our analysis of relative volatility indicates that prior to the crisis individuals held portfolios with an average standard deviation 54\% larger than the market portfolio's standard deviation. During the crisis this figure dropped to $26 \%$ larger; this difference is statistically significant at the $1 \%$ level. During the crisis individuals adjusted their portfolios to hold stocks with larger capitalization, lower (excess) volatility, larger government ownership and higher liquidity. These adjustments are more pronounced for small investors. The shift to less risky portfolio holdings could be driven by the increasing risk aversion of individual investors during the crisis period, consistent with the survey results of Guiso, Sapienza and Zingales (2013).

In summary, our analysis, free from the influence of trading motivated by tax, short positions or margin requirements, provides evidence for marked differences in individual investment behavior during a financial crisis versus their pre-crisis behavior. Investors tended to withdraw funds during the bull market while investing more during the crisis. During the crisis they revised their portfolios to hold lower risk assets. We also find support for the

\footnotetext{
${ }^{13}$ These results are consistent with the findings of Dhar and Zhu (2006).
} 
notion that behavioral biases such as the disposition effect are amplified during a crisis and are more pronounced in smaller investors.

The rest of this paper is organized as follows. Section 2 provides a brief background on the Chinese stock market, data description and sample construction. Section 3 describes the methodology and results on the net account flows, disposition effect and the portfolio risk and characteristics over different sample periods. Our conclusions are presented in Section 4 .

\section{The Chinese stock market, data and sample}

\subsection{Chinese equity markets ${ }^{14}$}

The Chinese stock market consists of two national stock exchanges: the Shanghai Stock Exchange (SHSE), established on December 17, 1990, and the Shenzhen Stock Exchange (SZSE), known as ChiNext, established on July 13, 1991. ${ }^{15}$ The SHSE is the largest stock exchange in mainland China and third largest in the world, with a market capitalization of US $\$ 2.99$ trillion. ${ }^{16}$ SZSE has a market capitalization of US\$0.774 trillion. SHSE consists of more large capitalization stocks than the SZSE. Cross listing is not allowed on the two exchanges. Transactions are standardized through an over-the-counter network known as the Securities Trading Automated Quotation System, under which brokerage houses throughout the country buy and sell these securities on the behalf of investors.

There are two types of shares listed on the Chinese stock market: A-shares, which are only available to domestic Chinese investors, and B-shares, which could be held only by foreign investors prior to February 19, 2001. After that date B-shares were opened to domestic investors. By the end of our sample period, there were a total of 1,638 A-shares and 111

\footnotetext{
${ }^{14} \mathrm{See} \mathrm{Su}$ (2003) for a more complete description of China's equity markets.

${ }^{15}$ On November 1, 2009, the Growth Exchange Market (GEM) opened. At the end of its first day of trading it represented a market capitalization of $\$ 20$ billion.

${ }^{16}$ As of November 2009 , the other largest world equity markets were the U.S. (\$13.1 trillion), Japan (\$3.5 trillion), the U.K. (\$2.9 trillion) and Hong Kong ( $\$ 2.2$ trillion).
} 
B-shares listed, of which 876 A-shares and 54 B-shares are listed and traded on the SHSE, and $762 \mathrm{~A}$-shares and 57 B-shares are on the SZSE. Since the B-share market is small, ${ }^{17}$ relatively inactive and transactions are made in U.S dollars in SHSE and HongKong dollars in SZSE, we did not include B-shares in our analysis.

Individual investors in China mostly hold only one account, so we are able to track all the stock trading activities for our sampled investors. ${ }^{18}$ Margin trading and short selling were not allowed in the Chinese stock markets during our sample period. Hence, investors had neither negative stock holdings nor negative investment values in their account. As earlier noted, it is very important to our study that individual investors in China do not pay capital gains taxes on stock market investment income. Our sample thus allows us to focus on the trading behavior of investors without the confounding effects of tax-motivated transactions.

\subsection{Data description and sample construction}

A nationwide discount broker in China provided the data for this study. ${ }^{19}$ A sample of 15,040 customer accounts was randomly selected from all existing accounts in the beginning of 2005. Among them, there are 12,364 active investors who made at least one trade during our sample period. The data consist of three files: an account file, a trade file and a position file. The account file includes the customer code, gender, age, total account value and total market value of the stock investment at the end of November 2008. The trade file includes the records of all trades made in the 15,040 accounts from January 2005 through November 2008. There are a total of 2,357,959 trade records and each record has a customer code, a security code, trade date and time, a buy-sell indicator and the price and quantity of the trade. The position file contains positions held by each customer at the end of November 2008. Combining the position file and trade file, we can determine the investor portfolio

\footnotetext{
${ }^{17} \mathrm{~B}$-shares represent only about $2 \%$ of the total market.

${ }^{18}$ See Feng and Seasholes (2004).

${ }^{19}$ Since different brokers in China provide similar services and charge comparable fees for their investors, there is no evidence showing that one broker could attract certain types of customers. Also, because the broker providing the data in this study is nationwide, we believe that our sample is representative of the population of individual investors in China.
} 
holdings in each month. The stocks in our dataset are A-shares listed on the Shanghai or Shenzhen Stock Exchange. ${ }^{20}$ The monthly returns for each security and market indices are downloaded from DataStream. The value weighted average returns of the SHSE A-share Index and the SZSE A-share Index are used as market returns.

Our data cover a dramatic crisis period, starting from November 2007. The stock market index fell to less than one third of its previous value within these 13 months. The monthly SHSE A-share Index dropped from its highest monthly level of 5,955 to 1,871 by the end of November 2008; the SZSE A-share Index dropped from 19, 531 to 6, 658. See Figure 2 for the monthly level of the SHSE A-share Index during our sample period.

We divide the entire sample into two subperiods: the pre-crisis period (January 2005 to October 2007), and the crisis period (November 2007 to November 2008). The choice of the starting date for the crisis was obtained by using a two-state regime switching analysis of the monthly market returns. ${ }^{21}$

To provide more insight into investor trading behavior during our sample period and to further test the robustness of our results, we also partition the pre-crisis period into a low volatility period (January 2005 to August 2006) and a rapidly rising bull market (September 2006 to October 2007). We further split the crisis period into two intervals: November 2007 to April 2008 and May to November 2008.

Summary statistics for the return and volatility of these subperiods are presented in Panel A of Table 1. The average monthly return is $5.5 \%$ in the pre-crisis period, which is in sharp contrast to the magnitude of $-6.8 \%$ over the crisis period. This difference is even larger when we compare the period encompassing the bull market (average returns of 10.5\%) and the crisis periods. The monthly standard deviation over the crisis period was $13.4 \%$ compared to $9.4 \%$ in the pre-crisis period. This sharp shift in market conditions provides a unique setting to study the behavior of individual investors. Panel A of Table 1 also shows several summary

\footnotetext{
${ }^{20}$ Among all the A-shares trading in China, individual investors represented $45.4 \%$ of the market in 2008 .

${ }^{21}$ See Hamilton (1989).

The estimation programs are from http://weber.ucsd.edu/ jhamilto/software.htm\#Markov.
} 
statistics for investor portfolios. The average value weighted portfolio returns of individual investors show similar patterns as the market returns in the different sample period. The portfolio excess returns, measured by the difference between the portfolio returns and market returns, are negative in the pre-crisis periods, and positive in the crisis period, especially during the first half of the crisis. The relative portfolio volatility, measured by the ratio of portfolio volatility to market volatility, is larger than one, with the largest value achieved in the bull market period. This gives us a broad view of the relative risk taking behavior of individual investors during different sample periods.

The summary statistics for the investor characteristics are listed in Panel B of Table 1. We summarize investor characteristics using three dummy variables. These dummy variables take on the value of one for female investors, investors whose age is below the median and investors whose investment size is below the median, respectively; the variables are set to zero otherwise. The median age of the investors in our sample is 45 , and the median investment size is $85,186 \mathrm{RMB}$, where the investment size is defined as the maximum monthly portfolio value. ${ }^{22}$ For simplicity, we define investors whose investment sizes are above the median and below the median as large investors and small investors, respectively. As Panel B shows, there is a large disparity between the large and small investors in our sample; the median investment size of the large investors is 8.8 times larger than for small investors.

\section{Methodology and results}

\subsection{Summary of net account flows}

We first characterize how individual investors adjust their levels of stock investment before and during the crisis period. We initially focus on the aggregate investment changes over the entire sampled investors. We measure the investment changes in three ways: net flows,

\footnotetext{
${ }^{22}$ If we measure investment size by the average monthly portfolio value over the entire sample, our results still hold.
} 
active net flows and proportional net flows. These measures are defined as follows:

Net flow: the value of stocks purchased minus the value of stocks sold evaluated at the actual trading price, accumulated over all investors during a specified period.

Active net flow: the value of stocks purchased minus the value of stocks sold evaluated at the beginning-of-period price, accumulated over all investors during a specified period.

Proportional net flow: the active net flow divided by the beginning-of-period portfolio value, if the active net flow is negative; the active net flow divided by the sum of the beginning-of-period portfolio value and the active net flow, if the active net flow is positive. The beginning-of-period portfolio value is the portfolio holding times the corresponding stock prices at the beginning of the period.

The net flow measures the total changes in the investor's stock investment. It contains the active investment adjustment and the effects of changing prices during each period. The active net flow measures the investor's investment decisions and is not distorted by changing prices during a specified period. Proportional net flow measures the percentage of the active investment change.

For example, suppose that during the first half of the crisis, the value of the beginning-ofperiod portfolio is 4,500 RMB; the investor bought 100 shares of stock A at $8.50 \mathrm{RMB}$ per share and then sold these at 8.00 RMB per share. She then bought 200 shares of stock B at 10.00 RMB per share. The beginning-of-period price of stocks $\mathrm{A}$ and $\mathrm{B}$ are $8.80 \mathrm{RMB}$ and 11.00 RMB, respectively. The net flow is then $100 \times 8.50-100 \times 8.00+200 \times 10.00=2,050$. The active net flow is $100 \times 8.80-100 \times 8.80+200 \times 11.00=2,200$. The proportional net flow is $\frac{2200}{4500+2200}=32.84 \%$.

The results for aggregate investment changes are listed in Panel A of Table 2. The three measures of net flows are calculated over different sample periods: the entire sample, the pre-crisis period (normal and bull market periods), the crisis period (first half and second half) and each month during the crisis. $^{23}$ The three measures of net flows generally have

\footnotetext{
${ }^{23}$ To eliminate the impact of a few very large investors on the net flow analysis, we dropped the 10 largest investors (based on the total value of stocks purchased or sold over the entire sample period. Our results are
} 
the same sign and show similar patterns across the different sample periods. Focusing on the proportional net flows, during the crisis investors increased their stock investment by 16.83\%. This increase comes mainly in the first half of the crisis, when the increase averages $13.17 \%$. In the second half of the crisis, investors increased their investment by $3.66 \%$. This trend is also evident from the monthly flows during the crisis. The proportional net flows are strictly positive during the first half of the crisis, followed by only two outflows in the middle and the end of the second half of the crisis. In contrast, investors, in aggregate, reduced their investment in the pre-crisis period, with the proportional net flows of $-12.03 \%$. These withdrawals occur mostly in the bull market period.

However, the aggregate net flows disproportionately reflect the behavior of relatively large investors. Thus, we calculate the three measures of net flows for each investor in each month. We report the average investment changes over various sample periods. For example, we redefine the active net flow of individual investor $i$ in month $t$ as the value of stocks purchased minus the value of stocks sold by individual $i$ over month $t$, evaluated at the beginning-of-month price.

Panel B of Table 2 shows the average net flows at the investor-month level. Again, we focus on the analysis of proportional net flows. These results are similar to those found in our analysis of the aggregate net flows. Individual investors have average monthly inflows of $2.63 \%$ during the crisis period and average monthly outflows of $1.28 \%$ in the pre-crisis period. Average proportional net flows are positive in both halves of the crisis. Studying the crisis month-by-month, we find that most proportional net flows are significantly positive. The only significant negative value $(-5.49 \%)$ occurs at the end of the crisis period. ${ }^{24}$ Compared to the aggregate proportional net flow of $-1.18 \%$ in Panel A of Table 2 , this result reflects the poor timing ability of small investors. In the pre-crisis period, we find significant negative proportional net flows in both the normal and bull market periods.

This analysis of aggregate and average investment changes using different measures of virtually unchanged if we retain these observations.

${ }^{24}$ This is also near the lowest index level from the beginning of the crisis to the present. 
net flows suggests that individual investors did not withdraw their capital during the crisis. Instead, investors invested significantly more as measured by proportional net flows. They were more likely to withdraw capital during the period of rising prices, supporting our first hypothesis that investors' cash flow patterns are different in the pre-crisis and crisis periods. These findings are in contrast to the selling behavior of institutional investors during the market downturns. ${ }^{25}$

\subsection{Panel analysis of proportional net flows}

In this subsection, we analyze the monthly proportional net flows to investigate how the investor and portfolio characteristics affect the cash flow decisions differently during the pre-crisis and crisis periods. We use Proportional net flow $i t$ to mitigate the effect of large investors and measure the active investment changes. For simplicity, we assume that all transactions occur at the end of each month. ${ }^{26}$

We follow the existing literature and include the following factors that have been shown to influence an individual's trading decisions. Grinblatt and Keloharju (2001), using a logit regression to identify the determinants of buying and selling decisions, find that past returns and historical price patterns influence trading. Barberis, Huang and Santos (2001) show that investors react differently to past losses and past gains, and that they are loss averse. In addition, individual characteristics, such as trading experience, investment sizes, age and gender have been shown to sway the trading behavior of individual investors. ${ }^{27}$ To include all of these possible effects, we apply the following linear regression framework to the panel data:

$$
\text { Proportional net } \text { flow }_{i t}=\text { Crisis }_{t}+\text { Crisis }_{t} \cdot X_{i t}+X_{i t}+\epsilon_{i t}
$$

The independent variables are defined as follows:

\footnotetext{
${ }^{25}$ See Ben-David, Franzoni and Moussawi (2012).

${ }^{26}$ These results are unchanged if we assume that all transactions are at the beginning of each month.

${ }^{27}$ For example, Barber and Odean (2001) document that men are more overconfident than women in stock trading, and trade more frequently. Dhar and Zhu (2006) show that wealthier investors and investors with higher trading frequency show smaller behavioral bias.
} 
Crisis $_{t}$ : a dummy variable that takes on the value of one during the crisis and zero otherwise;

$X_{i t}$ : the vector of potential determinants of investment changes for individual $i$ at month $t$, consists of:

Positive past return $_{i t}$ and Negative past return $i t$ : the value weighted portfolio returns of individual $i$ in month $t-1$, partitioned into positive and negative observations in order to capture potentially asymmetric reactions to past gains and losses. ${ }^{28}$

Past volatility P $_{\text {: }}$ the standard deviation of the value weighted portfolio of returns over the previous 12 months ending in month $t-1$. Portfolio volatility, as a measure of risk taking behavior, is assumed to be negatively related to investor risk aversion.

Investment size dummy , Age dummy $_{i}$ and Gender $_{i}$ : three dummy variables as defined earlier.

Past portfolio turnover ${ }_{i t}$ and Number of stocks $_{i t}$ : represent the monthly portfolio turnover ${ }^{29}$ of individual $i$ in month $t-1$, and the beginning-of-month number of stocks in the portfolio of individual $i$ in month $t$, respectively. They act as proxies for the investor's trading experience. $^{30}$

Crisis $_{t} \cdot X_{i t}$ : our key measure of the differences in reactions to the factors in the pre-crisis and crisis periods.

The model is estimated on the entire dataset as a pool. This approach can underestimate standard errors when the individual-month observations are not independent. Therefore, we calculate the clustered standard errors, clustering both by individual level and by time. ${ }^{31}$

\footnotetext{
${ }^{28}$ Note that the Negative past returns are presented in terms of negative values.

${ }^{29}$ Portfolio turnover is calculated using the average of the portfolio buying turnover and selling turnover, following Barber and Odean (2001). Sell turnover for individual $h$ at month $t$ is $\Sigma_{i=1}^{s h_{t}} p_{i t} \min \left(1, S_{i t} / H_{i t}\right)$, where $S_{i t}$ is the number of shares in security $i$ sold during the month, $p_{i t}$ is the value of stock $i$ held at the beginning of month $t$ divided by the total value of stock holdings, $H_{i t}$ is the number of shares of security $i$ held at the beginning of month $t$, and $s h_{t}$ is the number of individual investors at month $t$. Buy turnover is $\Sigma_{i=1}^{s h_{t}} p_{i, t+1} \min \left(1, B_{i t} / H_{i, t+1}\right)$, where $B_{i t}$ is the number of shares of security $i$ bought during the month.

${ }^{30}$ Portfolio turnover is sometimes used as a measure of investor overconfidence. We will show later that the negative relation between portfolio turnover and net flows does not support the role of overconfidence in our data.

${ }^{31}$ See Petersen (2009) for discussion.
} 
We report the results for the proportional net flows in Table 3. Column (1) uses all observations. The significant positive coefficient on the crisis dummy shows that investors increase their stock investment during the crisis period compared to the pre-crisis period. In the pre-crisis period, the proportional net flow is negatively related to positive past returns with a coefficient of -0.127 (significant at the $1 \%$ level), but has an insignificant relation with negative past returns. This finding is consistent with the disposition effect, which predicts that investors are more likely to realize gains than losses. Hence, investors tended to sell a larger proportion of their portfolio following positive past returns. In addition, the significant negative coefficient of -0.235 on the product of the crisis dummy and positive past return means that investors, experiencing the same level of positive past returns, are likely to sell a larger proportion of their portfolios during the crisis than prior to the crisis. This finding suggests that the disposition effect is stronger during the crisis period.

Furthermore, three other investor and portfolio characteristics show significantly different effects during the crisis period. Larger investors have proportionally greater inflows in the pre-crisis period compared to smaller investors, but this difference diminishes during the crisis period. Relatively younger investors withdraw more money from the stock market than older investors in the pre-crisis period, but this age effect reverses itself during the crisis. In addition, investors with higher past portfolio turnover withdraw more capital in both periods, and this cross-sectional difference is more significant during the crisis. This finding is consistent with Dhar and Zhu (2006), who show that individuals who trade frequently are more willing to sell losers.

The investment differences in the pre-crisis and crisis periods can be influenced by varying reactions to the bull market period. We thus conduct the same regression analysis using observations from the normal market period and the crisis period, excluding those from the bull market period. These results are shown in column (2) of Table 3. Despite the smaller magnitudes of the coefficients, we find patterns similar to those found in the entire sample period. Compared to the normal period, investors were more likely to reduce equity 
investments following past portfolio gains and to increase their proportional net flows during the crisis period.

As an additional robustness check, we also partition the crisis period into two subperiods. The results based on the pre-crisis period and the first half of the crisis are listed in column (3); those related to the second half of the crisis are given in column (4). Both regressions yield consistent results, but the effects estimated in the second half of the crisis show larger coefficients on the crisis dummy and on the product of the crisis dummy and positive past returns.

In results not detailed here, we also conducted an analysis of the proportional net flows using market adjusted, value weighted portfolio returns. ${ }^{32}$ The same patterns hold. Overall, we can conclude that individual investors did not withdraw their capital from the equity market during the crisis; rather they invested more money than they did in the pre-crisis period. A significant negative relation exists between the proportional net flows and positive past returns under all specifications, but no significant relation exists between net flows and negative past returns. The asymmetric relation between net flows and past portfolio returns is consistent with the disposition effect. Furthermore, the net flow elasticity of positive past returns is much larger during the crisis than in the pre-crisis period. This shows that individual investors were relatively quicker to realize their gains during the crisis.

\subsection{Time-series analysis of the disposition effect}

In this section, we conduct formal tests of the disposition effect and speak to our second hypothesis of the dynamics of the disposition effect over the crisis period. Following the approach of Odean (1998) and Barber, Lee, Liu and Odean (2007), we test the frequency with which investors sell winners and losers relative to their opportunities to sell each. In each month, we define realized gains as the value of stocks sold at higher prices than their

\footnotetext{
${ }^{32}$ Barberis and Huang (2001), Grinblatt and Han (2005) and Glaser and Weber (2009) document the impact of different measures of return in investors' "mental accounting." They find that investors react similarly to all of the measures, albeit to different degrees.
} 
average purchase prices, and realized losses as the value of stocks sold at lower prices than their average purchase prices. We define paper gains as the value of stocks in the portfolio with higher end-of-month prices than their average purchase prices, and paper losses as the value of stocks with lower end-of-month prices than their average purchase prices. Realized gains, realized losses, paper gains and paper losses are calculated monthly for each investor. We then calculate two ratios monthly for each investor as follows:

$$
\begin{aligned}
& \frac{\text { Realized gains }}{\text { Realized gains }+ \text { Paper gains }}=\text { Proportion of gains realized }(P G R) \\
& \frac{\text { Realized losses }}{\text { Realized losses }+ \text { Paper losses }}=\text { Proportion of losses realized }(P L R)
\end{aligned}
$$

Testing the disposition effect means testing $P G R-P L R>0$. These results are reported in Panel A of Table 4. The differences in proportions using $P G R-P L R$ are significantly positive in all sample periods. In the pre-crisis period PGR was $23.5 \%$ while PLR was $19.6 \%$, indicating that the disposition effect, while present, was relatively weak. In the crisis period, PGR and PLR both declined significantly, with PGR falling by $3.0 \%$ and PLR falling by $6.6 \%$, implying that the disposition effect was stronger during the crisis period.

Furthermore, we calculated the average disposition effect of each investor to exclude the possibility that most PGR and PLR are from investors of a particular type. We define the disposition effect of investor $i$ as:

$$
\text { Disposition Effect }{ }_{i}=\frac{1}{T} \sum_{t=1}^{T}\left(P G R_{i t}-P L R_{i t}\right)
$$

where $T$ represents the total number of months during a given period, $P G R_{i t}$ and $P L R_{i t}$ are calculated above using realized gains, realized losses, paper gains and paper losses of individual investor $i$ in month $t$.

Panel B of Table 4 reports the disposition effect at the individual investor level. Again, we find that, on average, the disposition effect is present for all investors over all the different 
sample periods. The disposition effect in the crisis period is significantly larger than in the pre-crisis period by a magnitude of $2.6 \%$. This result holds for both large and small investors. However, larger investors are less prone to the disposition effect than smaller investors; these cross-sectional differences are significant over all the periods. ${ }^{33}$

\subsection{Relative portfolio volatility}

We further investigate our third hypothesis regarding the dynamics of individual risk taking. We compute for each investor in each sample month the relative portfolio volatility, defined as the individual portfolio standard deviation divided by the market portfolio's standard deviation. Both are rolling 12-month estimates. Since volatility was much higher during the crisis period, we use the volatility ratio to measure the relative risk taking behavior of individual investors. We plot the average monthly relative portfolio volatility of investors in Figure 3. From January 2005 to October 2007 the relative portfolio volatility averages 1.564 with a slight upward trend. As the crisis period begins, however, the ratio begins to decline, reaching its lowest level at the end of our sample period. The average relative volatility during the crisis period is 1.259 ; this figure is significantly smaller than the pre-crisis figure at the $1 \%$ level. This analysis suggests that investors reduced their portfolio risk as the crisis evolved, which is in contrast with the results in Hoffman, Post and Pennings (2013).

These results (albeit informally), shed some light on the preferred risk habitat concept developed in Dorn and Huberman (2005): individuals tend to select stocks not within a portfolio context, but independently based on the level of risk that they are comfortable with; i.e., investors tend to focus on stocks with a specific volatility. Figure 3 implies that the preferred habitat theory holds during the bull market, but during the crisis investors seem to shift towards stocks with lower relative risk.

We further analyze the dynamics of the relative volatility changes at the individual

\footnotetext{
${ }^{33}$ The cross-sectional differences of large and small investors are similar to the findings in Dhar and Zhu (2006).
} 
investor-month level using the following regression:

$$
\text { Relative Portfolio Volatility } \text { Vrt }=\text { Crisis }_{t}+\text { Crisis }_{t} \cdot X_{i t}+X_{i t}+\epsilon_{i t}
$$

where Crisis $_{t}$ is defined the same as in Equation (1), and $X_{i t}$ includes Positive past return $_{i t}$, Negative past return ${ }_{i t}$, Investment size dummy , Age dummy $_{i}$, Gender ${ }_{i}$, Past portfolio turnover $_{i t}$, and Number of stocks $s_{i t}$, which are all defined in Equation (1).

Table 5 reports the estimation results with standard errors clustered both by individual level and by time. These regressions are relatively powerful as the average adjusted $R^{2} s$ are around 20\%. Column (1) uses all observations. The crisis dummy is negative and significant at the $1 \%$ level, consistent with our earlier results showing that during the crisis investors reduced their relative portfolio risk. The coefficient on positive past returns is 1.564 and that on the negative past returns is -2.249 , suggesting that in the pre-crisis period, investors react to large portfolio return changes (either positive or negative) by taking on more risk. ${ }^{34}$ However, during the crisis, investors take on less risk (in comparison to the pre-crisis period) when experiencing negative past returns, as the interaction term of crisis dummy and negative past return has a significant positive coefficient of 1.482 . The significant negative signs on the investment size, age and gender dummies imply that larger, older and female investors in general take less risk in the pre-crisis period. During the crisis periods, the difference between large and small investor disappears. ${ }^{35}$ Investors holding more stocks tend to have lower risk in the pre-crisis period, but this cross-sectional difference is reduced during the crisis period.

Column (2) of Table 5 excludes observations from the bull market period. Here we find patterns similar to those found in the entire sample period, which shows our previous results are not solely driven by the bull market. All variables that were significant in the

\footnotetext{
${ }^{34}$ Note that negative past returns are negative values. With the coefficient being negative, larger losses are associated with more risk taking.

${ }^{35}$ The coefficient of Investment size dummy is -0.0454 , and the coefficient of the interaction of Crisis dummy and Investment size dummy is 0.0463 , which implies the investment size effect during the crisis period is close to zero.
} 
entire sample retain their significance. However, two additional interaction terms are now significant. Compared to the pre-crisis low volatility period, investors risk taking following past portfolio gains is reduced during the crisis period.

We also partition the crisis period into two subperiods. The results based on the precrisis period and the first and second half of the crisis are in columns (3) and (4). Both regressions yield consistent results, but again the estimated from the second half of the crisis show larger coefficients on the crisis dummy and on the product of the crisis dummy and investment size.

Overall, we find strong evidence that investors reduce their relative portfolio risk during the crisis period, in particular following negative past portfolio returns in comparison to the pre-crisis period.

\subsection{Portfolio characteristics of individual investors}

The dynamics of the relative portfolio risk changes could partially be driven by passive changes in stock characteristics. In this subsection, we hold stock characteristics constant over the sample periods, and examine the active portfolio revisions of individual investors during the crisis.

We consider static measures of stock characteristics during the sample period, so that the changes in investor portfolio characteristics can only be driven by actual trades. There are five measures for each stock, with averages taken over the entire sample:

Size $_{j}$ : the average monthly market capitalization of stock $j$;

Volatility $_{j}$ : the standard deviation of monthly returns of stock $j$;

Excess volatility : the standard deviation of the monthly excess returns of stock $j$, where monthly excess return is the difference between the stock return and market return;

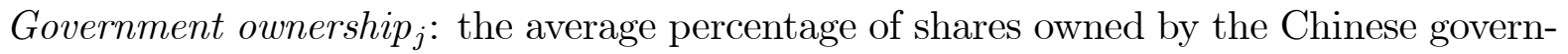
ment; ${ }^{36}$

\footnotetext{
${ }^{36}$ Government ownership is measured by the percentage of non-tradable shares over total shares. Non-
} 
Illiquidity $_{j}$ : measured by the average ratio of the absolute value of monthly returns to volume of stock $j$ (Amihud 2002);

Size and government ownership are negatively related to stock risk; volatility, excess volatility and illiquidity are positively related to risk.

To examine the portfolio characteristics of individual investors, we first divide all stocks into deciles based on the above five measures in ascending order. We define $g_{j}(=1, \ldots, 10)$ as the rank of the characteristic group containing stock $j$. For example, $g_{j}$ takes the value 1 if stock $j$ is in the group with the smallest size or lowest volatility, etc.. It takes the value 10 if stock $j$ is in the group with the largest size or highest volatility, etc.

The average characteristics based on the ten groups are summarized in Panel A of Table 6. The characteristics within these groups vary enormously. For example, the average size in the smallest group is 0.65 billion RMB, while it is 116.0 billion RMB in the largest decile. The average volatility ranges from 0.11 to 0.40 . Average excess volatility is slightly smaller than (unadjusted) volatility. Average government ownership is an important characteristic of Chinese equities; it also varies greatly, ranging from $31 \%$ in the lowest group to $84 \%$ in the highest group.

The monthly, value weighted, Individual Portfolio Characteristics $\left(I P C_{i t}\right)$ are then defined as:

$$
I P C_{i t}=\frac{\sum_{j=1}^{N_{i t}} \text { Value of } \text { stocks }_{i, j, t} \times g_{j}}{\text { Value of portfolio }{ }_{i, t}}
$$

where $g_{j}(=1, \ldots, 10)$ is the rank of the characteristic group containing stock $j$;

$N_{i t}$ is the total number of stocks held by individual $i$ at time $t$;

Value of portfolio $i, t$ is the beginning-of-month portfolio value of individual $i$ at time $t$;

Value of stocks $_{i, j, t}$ is the value of stock $j$ held in the beginning-of-month portfolio of individual $i$ at time $t$.

Panel B of Table 6 reports the results of the individual portfolio characteristics in the pre-

tradable shareholders are the Chinese government and legal persons. Legal-person shares are held primarily by quasi-government entities or at the very least firms with strong government affiliations. See Calomiris, Fisman and Wang (2010) and Li, Wang, Cheung and Jiang (2011). 
crisis and crisis periods. The results from the entire sample show that individual investors hold relatively large stocks, since the average portfolio size, 7.159 , is larger than 5.5 .37 The illiquidity measure of 3.793 shows that individual investors hold relatively liquid stocks. The differences from the average values in the other characteristics is not particularly large.

Our focus is on the differences in the portfolio characteristics prior to and during the crisis period. Overall the results in Panel B show relatively small, but statistically significant results. $^{38}$ In aggregate, we find that during the crisis period, investor portfolios shifted to stocks with larger size, lower (excess) volatility, more government ownership and smaller illiquidity. These trends hold for both large and small investors, but the magnitudes are larger for small investors. Collectively, these findings suggest that investors, especially small investors, shifted their portfolios to less risky stocks and more liquid stocks.

As a robustness check, we form calendar-time portfolios to reduce the cross-sectional correlations of the observations. We calculate the monthly, value weighted, Calendar-time Portfolio Characteristics $\left(C P C_{t}\right)$ as follows:

$$
C P C_{t}=\frac{\sum_{j=1}^{N_{t}} \text { Value of } \text { stocks }_{j, t} \times g_{j}}{\text { Value of calendar-time portfolio }}
$$

where $g_{j}$ is defined as above;

$N_{t}$ is the total number of stocks held by all investors at time $t$;

Value of stocks ${ }_{j, t}$ is the value of stock $j$ held by all investors at the beginning of month $t$;

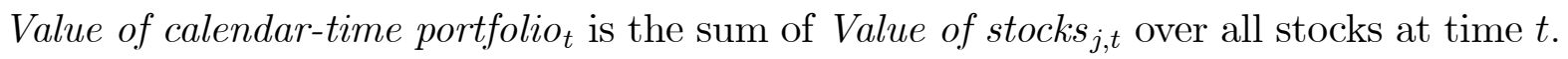

The results of the calendar-time portfolio characteristics are listed in Panel $\mathrm{C}$ of Table 6. The characteristic changes before and during the crisis for small investors are all significant at the $1 \%$ level and have magnitudes similar to those obtained for individual portfolios. However, large investors do not show a significant changes in terms of size, and the magni-

\footnotetext{
${ }^{37}$ In month $t$, if investor $i$ invests an equal amount of money in the stock of each group, then $I P C_{i t}=$ $\frac{1}{10} \sum_{n=1}^{10} n=5.5$.

${ }^{38}$ These relatively small changes are consistent with the asset allocation decisions of individuals documented in Brunnermeier and Nagel (2008), which shows that the major driving factor is inertia.
} 
tudes of adjustments for other characteristics are generally smaller than those obtained using individual portfolios. These results corroborate the result that the portfolio characteristic changes are mainly driven by small investors.

Again, these findings provide evidence that individual investors, especially small investors, tended to revise their portfolios to stocks with lower levels of risk and higher liquidity during the crisis. The lower portfolio risk during the crisis period shows further evidence of the increasing risk aversion of individual investors during the crisis period, consistent with the survey results of Guiso, Sapienza, and Zingales (2013).

\section{Conclusions}

This paper exploits a unique data set of individual trading accounts before and during the recent financial crisis in order to gauge the reactions of individual investors to this unprecedented event. Our sample choice allows us to abstract from trading based on capital gains taxation, short selling or margin requirements. In addition, we use data prior to the crisis in order to create a benchmark for analyzing investor behavior during the crisis.

We find that the net flows of individual accounts are relatively greater during the crisis than in the pre-crisis period. On average, they invested proportionately more capital relative to the period before the crisis. We further find that net flows are asymmetrically return sensitive: net flows are significantly negatively related to past positive returns, but have an insignificant relation with past negative returns. This asymmetrical return sensitivity is closely related to the tendency of individual investors to exhibit the disposition effect. We show that the disposition effect is present over our entire sample period and it is even stronger in the crisis period.

Analyzing the portfolio risk of individual investors, we find that during the crisis period, individual investors tended to lower their portfolio risk: prior to the crisis individuals held portfolios with an average standard deviation $54 \%$ larger than the market portfolio's standard 
deviation. During the crisis this figure dropped to $26 \%$ larger. They revised their portfolios to hold stocks with relatively less risk and more liquidity, specifically stocks with larger capitalization, lower (excess) volatility, larger government ownership and greater liquidity. These trends are especially significant for small investors.

These results show that while investor biases like the disposition effect were exacerbated during the crisis, investors did not panic. Instead they invested more capital into the equity markets and shifted their portfolios into lower risk assets. 


\section{References}

Amihud, Y. "Illiquidity and Stock Returns: Cross-section and Time-series Effects." Journal of Financial Markets, 5 (2002), 31-56.

Amihud, Y., Haim Mendelson, and Robert A. Wood. "Liquidity and the 1987 stock market crash." Journal of Portfolio Management, 16 (1990), 65-69.

Barber, B. M., Y. Lee, Y. Liu, and T. Odean. "Is the Aggregate Investor Reluctant to Realize Losses? Evidence from Taiwan." European Financial Management, 13 (2007), 423-447.

Barber, B. M., and T. Odean. "Boys Will Be Boys: Gender, Overconfidence, and Common Stock Investment." Quarterly Journal of Economics, 116 (2001), 261-292.

Barberis, N., and M. Huang. "Mental Accounting, Loss Aversion, and Individual Stock Returns." Journal of Finance, 56 (2001), 1247-1292.

Barberis, N., and W. Xiong. "What Drives the Disposition Effect? An Analysis of a Long-Standing Preference-Based Explanation." Journal of Finance, 64 (2009), 751-784.

Barberis, N., M. Huang, and T. Santos. "Prospect Theory and Asset Prices." Quarterly Journal of Economics, 116 (2001), 1-53.

Beber, Alessandro, Michael W. Brandt, and Kenneth A. Kavajecz. "Flight-to-Quality or Flight-to-Liquidity? Evidence from the Euro-Area Bond Market." Review of Financial Studies, 22(2009), 925-957.

Ben-David, I., F. Franzoni, and R. Moussawi. "Hedge Fund Stock Trading in the Financial Crisis of 2007-2009." Review of Financial Studies, 25 (2012), 1-54.

Brunnermeier, M. K., and S. Nagel. "Hedge Funds and the Technology Bubble." Journal of Finance, 59 (2004), 2013-2040.

Brunnermeier, M. K., and S. Nagel. "Do Wealth Fluctuations Generate Time-Varying Risk Aversion? Micro-Evidence on Individuals' Asset Allocation." American Economic Review, 98 (2008), 713-736.

Calomiris, C., R. Fishman, and Y. Wang. "Profiting from Government Stakes in a 
Command Economy: Evidence from Chinese Asset Sales." Journal of Financial Economics, 96 (2010), 399-412.

Choe, H., B. Kho, and R. M. Stulz. "Do Foreign Investors Destabilize Stock Markets? The Korean Experience in 1997." Journal of Financial Economics, 54 (1999), 227-264.

Dhar, R., and N. Zhu. "Up Close and Personal: Investor Sophistication and the Disposition Effect." Management Science, 52 (2006), 726-740.

Dorn, Daniel and Gur Huberman. "Preferred risk habitat of individual investors." Journal of Financial Economics 97 (2010), 155-173.

Dorn, Daniel and Martin Weber. "Individual investors' trading in times of crisis: Going it alone or giving up? Working paper (2013).

Giannetti, Mariassunta, and Andrei Simonov. "Which Investors Fear Expropriation? Evidence from Investors' Portfolio Choices." Journal of Finance 62 (2006), 1507-1547.

Glaser, M., and M. Weber. "Which Past Returns Affect Trading Volume?" Journal of Financial Markets, 12 (2009), 1-31.

Goyenko, Ruslan Y., and Andrey D. Ukhov. "Stock and Bond Market Liquidity: A Long-Run Empirical Analysis." Journal of Financial and Quantitative Analysis 44 (2009), $189-212$.

Grinblatt, M., and B. Han. "Prospect Theory, Mental Accounting, and Momentum." Journal of Financial Economics, 78 (2005), 311-339.

Grinblatt, M., and M. Keloharju. "The Investment Behavior and Performance of Various Investor Types: A Study of Finland's Unique Data Set." Journal of Financial Economics, 55 (2000), 43-67.

Grinblatt, M., and M. Keloharju. "What Makes Investors Trade?" Journal of Finance, 56 (2001), 589-616.

Guiso, Luigi, Paola Sapienza and Luigi Zingales. "Time varying risk aversion." Working paper (2013).

Hamilton, J. D. "A New Approach to The Economic Analysis of Nonstationary Time 
Series and the Business Cycle." Econometrica, 57 (1989), 357-384.

Hoffmann, Arvid, Thomas Post, and Joost Pennings. "Individual investor perceptions and behavior during the financial crisis." Journal of Banking and Finance, 37 (2013), 60-74.

Kahneman, D., and A. Tversky. "Prospect Theory: An Analysis of Decision Under Risk." Econometrica, 47 (1979), 263-292.

Karolyi, A. G. "Did the Asian Financial Crisis Scare Foreign Investors out of Japan?" Pacific-Basin Finance Journal, 10 (2002), 411-442.

Kaustia, M. "Prospect Theory and the Disposition Effect." Journal of Financial and Quantitative Analysis, 45 (2010), 791-812.

Kim, K., and J. R. Nofsinger. "The Behavior of Japanese Individual Investors During Bull and Bear Markets." Journal of Behavioral Finance, 8 (2007), 138-153.

Kim, K., and J. R. Nofsinger. "Behavioral finance in Asia." Pacific-Basin Finance Journal 16 (2008), 1-7.

Kim, W., and S. Wei. "Foreign Portfolio Investors Before and During a Crisis." Journal of International Economics, 56 (2002), 77-96.

Li, K., T. Wang, Y. Cheung, and P. Jiang. "Privatization and Risk Sharing: Evidence from the Split Share Structure Reform in China." Review of Financial Studies, 24 (2011), 2499-2527.

Lo, A., D. Repin, and B. Steenbarger. "Fear and greed in financial markets: A clinical study of day-traders. No. w11243. National Bureau of Economic Research, (2005).

Loewenstein, George. "Emotions in economic theory and economic behavior." American Economic Review 90 (2000), 426-432.

Loewenstein, George , Elke Weber, Christopher Hsee and Ned Welch. "Risk as feelings." Psychological Bulletin,127 (2001), 267-286.

Odean, T. "Are Investors Reluctant to Realize Their Losses?" Journal of Finance, 53 (1998), 1775-1798.

Odean, T. "Do Investors Trade Too Much?" American Economic Review, 89 (1999), 
1279-1298.

Petersen, M. "Estimating Standard Errors in Finance Panel Data Sets: Comparing Approaches." Review of Financial Studies, 22 (2009), 435-480.

Scholes, Myron S. "Crisis and Risk Management." American Economic Review, 90 (2000), $17-21$.

Shefrin, H., and M. Statman. "The Disposition to Sell Winners Too Early and Ride Losers Too Long: Theory and Evidence." Journal of Finance, 40 (1985), 777-790.

Slovic, Paul, Melissa Finucane, Ellen Peters and Donald G. MacGregor. "Risk as analysis and risk as feelings: Some thoughts about affect, reason, risk, and rationality." Risk Analysis 24 (2004), 311-322.

Su, D. Chinese Stock Markets: A Research Handbook. (2003) World Scientific Pub. Co. Inc.

Thaler, R. H., and E. J. Johnson. "Gambling with the House Money and Trying to Break Even: The Effect of Prior Outcomes on Risky Choice." Management Science, 36 (1990), 643-660.

Vissing-Jorgensen, Annette. "Perspectives on behavioral finance: Does "irrationality" disappear with wealth? Evidence from expectations and actions." NBER Macroeconomics Annual 2003, Volume 18 (2004). MIT Press. 139-208. 
Figure 1: Global Equity Market Capitalization (Billions of U.S. Dollars)

Figure 1 shows global equity market capitalization over the period December 2006 to November 2009. The equity markets lost \$32.2 trillion from November of 2007 to December of 2008; more than half of its initial value. Source: Bloomberg.

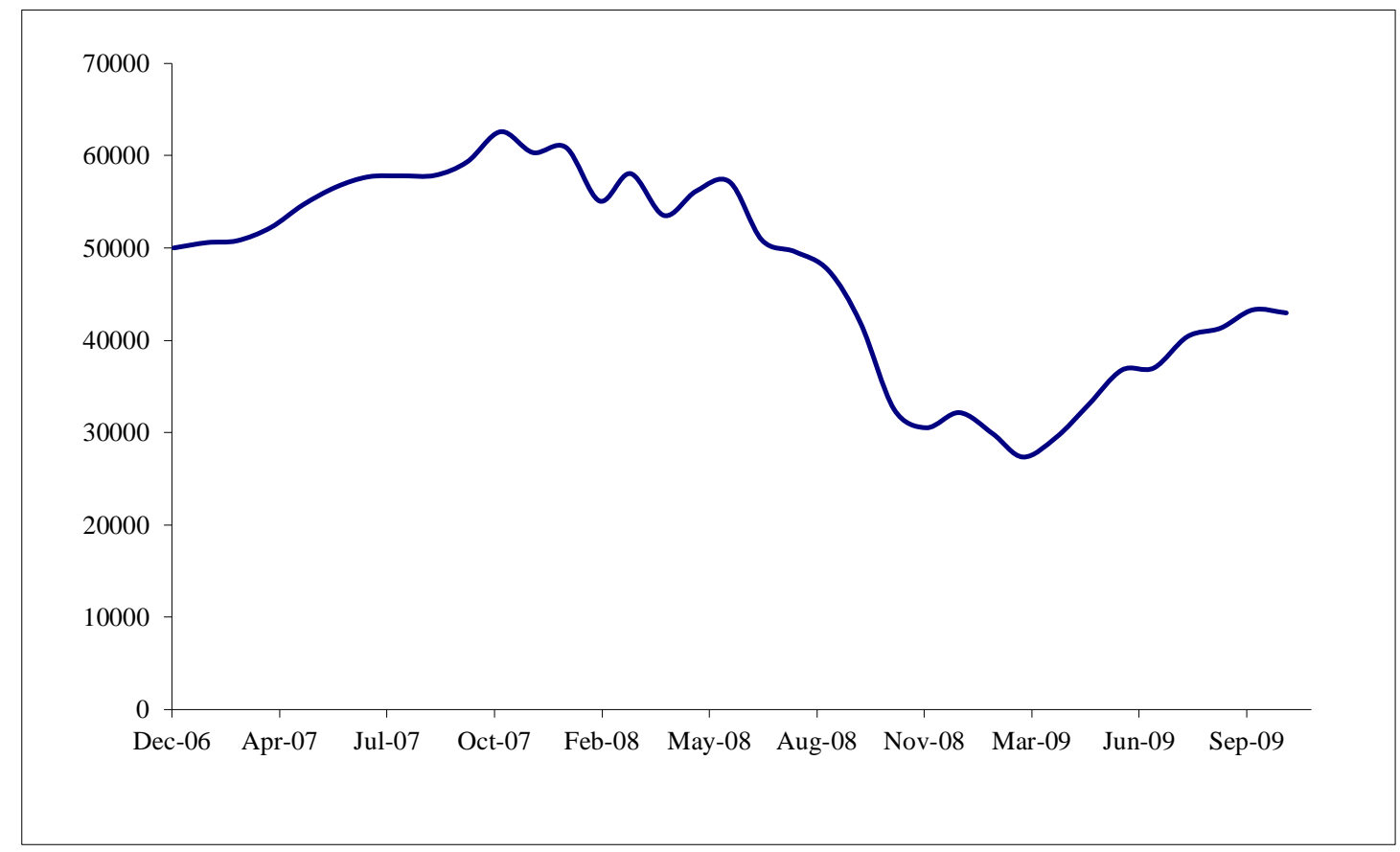


Figure 2: Shanghai Stock Exchange A-share Index

Figure 2 shows the monthly level of the Shanghai Stock Exchange A-share Index over the sample period. The Chinese Stock Market experienced a huge decline; the Shanghai Stock Exchange A-share Index fell from its monthly highest level of 5,955 to 1,871 by the end of November 2008. A regime switching model is used to determine the turning point from the pre-crisis period to the crisis period.

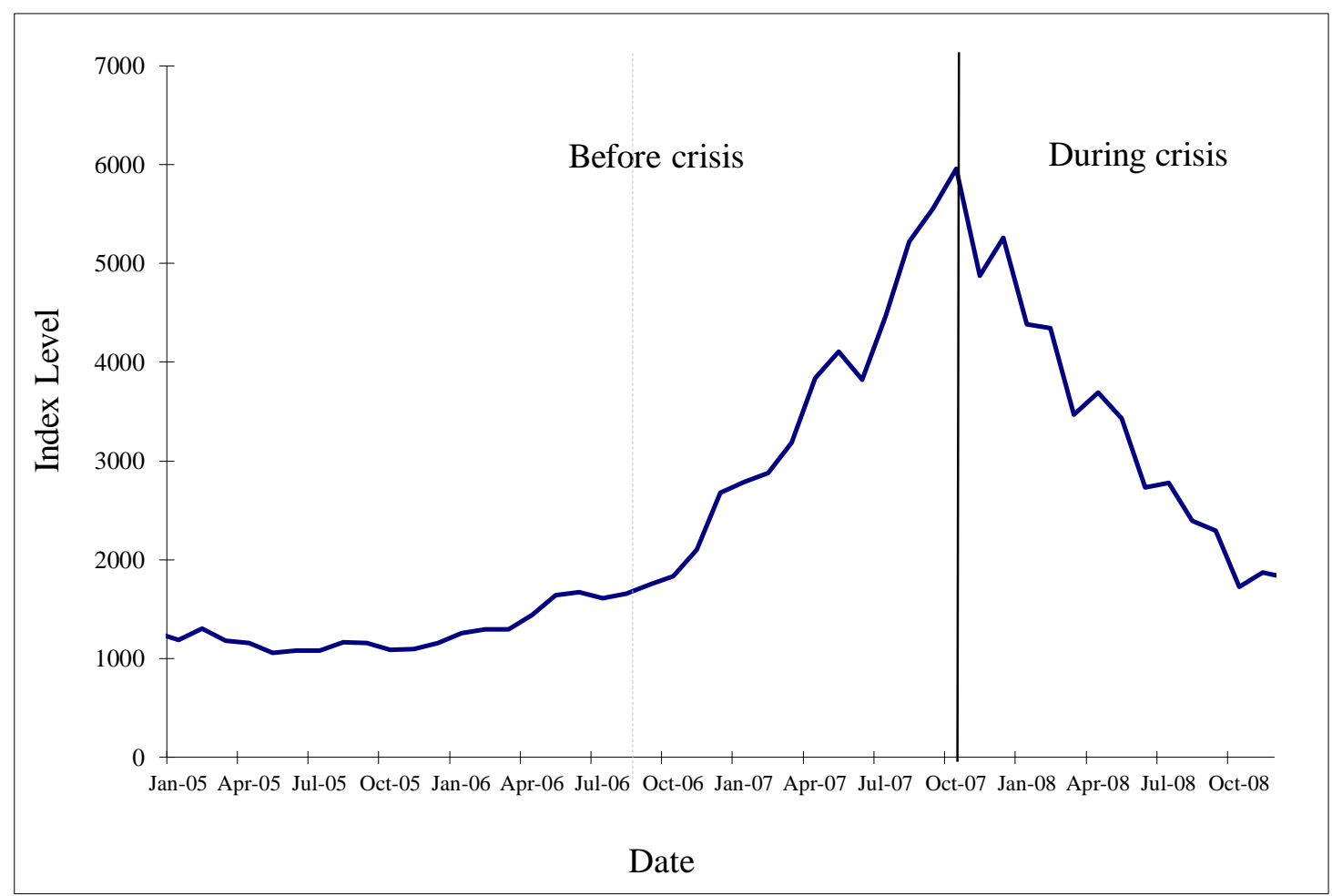


Figure 3: Relative Portfolio Volatility

Figure 3 shows the monthly level of the relative portfolio volatility over the sample period. The relative portfolio volatility is the monthly portfolio volatility divided by the monthly market portfolio volatility.

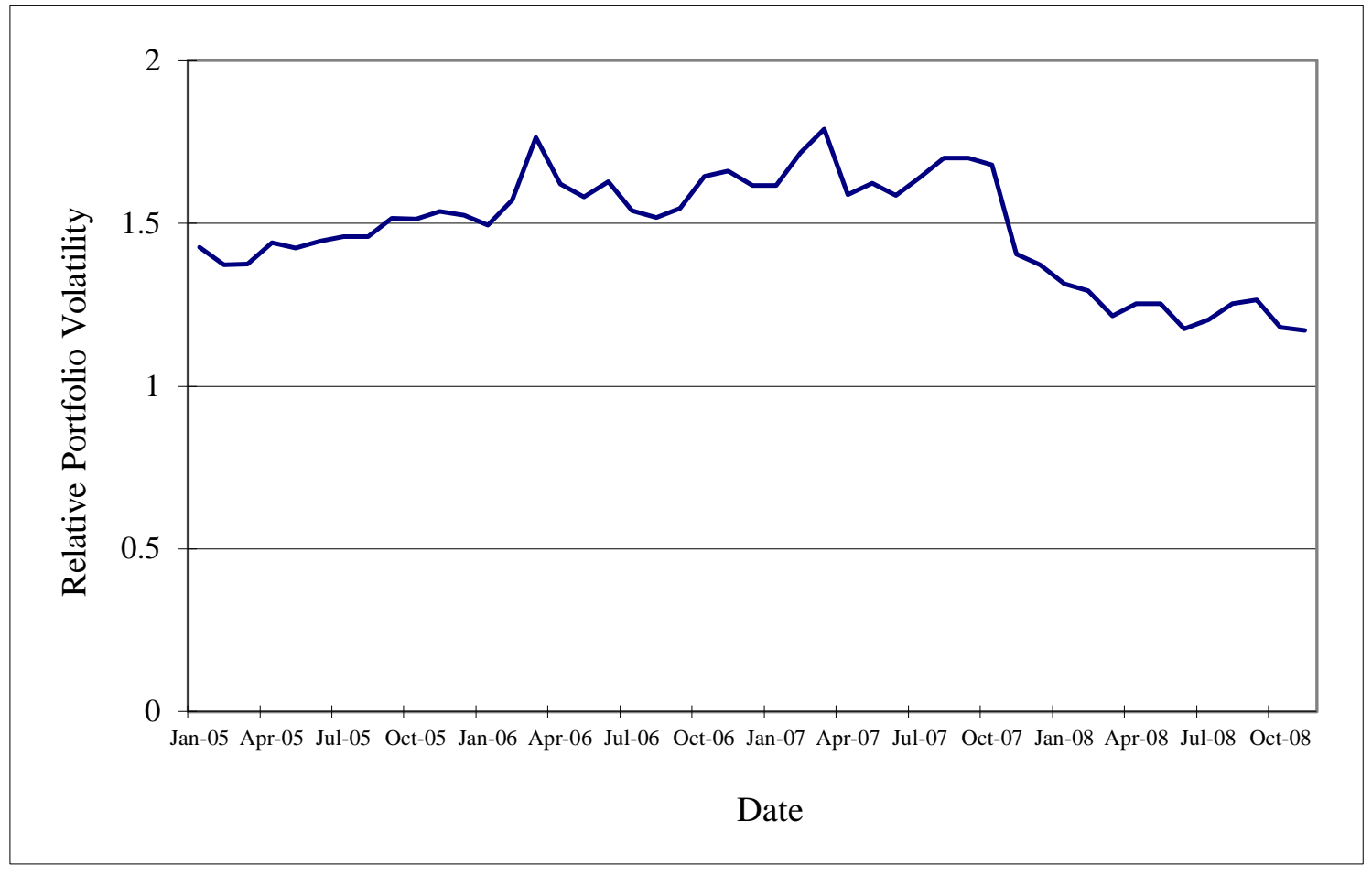


Table 1: Summary Statistics

Panel A displays the basic descriptive statistics for the Chinese stock market and investor portfolios during different periods of January 2005 to November 2008. The value weighted average monthly returns of the SHSE and SZSE A-share Indices are used as market returns. Market volatility is the standard deviation of the monthly market returns. The value-weighted portfolio returns are calculated using the beginning-of-month holdings of individual portfolios. The portfolio volatility is the standard deviation of the monthly portfolio returns. The excess portfolio returns are the value weighted portfolio returns minus the market returns. The relative portfolio volatility is the portfolio volatility divided by the market volatility. Portfolio turnover is half of the portfolio buying turnover plus half of the selling turnover. Panel B presents the summary statistics for the investor characteristics. The three dummy variables for investment size, gender, and age are set to one for investors whose investment size is above median, female investors, and investors whose age is above the median, respectively.

Panel A: Summary statistics for stock markets and individual monthly portfolios

\begin{tabular}{|c|c|c|c|c|c|c|c|}
\hline & $\begin{array}{c}\text { Entire } \\
\text { sample }\end{array}$ & Normal & Bull & Pre crisis & Crisis & $\begin{array}{c}\text { 1st half of } \\
\text { crisis }\end{array}$ & $\begin{array}{c}\text { 2nd half o } \\
\text { crisis }\end{array}$ \\
\hline Market return & 0.021 & 0.020 & 0.105 & 0.055 & -0.068 & -0.039 & -0.093 \\
\hline Market volatility & 0.119 & 0.075 & 0.105 & 0.094 & 0.134 & 0.131 & 0.143 \\
\hline Value weighted portfolio return & 0.015 & 0.005 & 0.096 & 0.040 & -0.061 & -0.029 & -0.090 \\
\hline Relative portfolio volatility & 1.361 & 1.547 & 1.743 & 1.617 & 1.239 & 1.199 & 1.182 \\
\hline Portfolio turnover (\%) & 4.612 & 2.266 & 7.759 & 4.411 & 5.231 & 6.423 & 4.176 \\
\hline
\end{tabular}

Panel B: Summary statistics for the characteristics of individual investors

\begin{tabular}{|c|c|c|c|c|c|c|c|}
\hline & \multicolumn{3}{|c|}{ Investment size dummy $(1,000 \mathrm{RMB})$} & \multirow{2}{*}{ Gender } & \multicolumn{3}{|c|}{ Age dummy } \\
\hline & Median & Mean & Std. dev. & & Median & Mean & Std. dev. \\
\hline Dummy $=0$ & 27.99 & 32.73 & 23.04 & Male & 38 & 37.4 & 5.5 \\
\hline Dummy=1 & 245.65 & 817.16 & 11700 & Female & 54 & 54.8 & 6.4 \\
\hline
\end{tabular}


Table 2: Summary of Net Flows of Individual Investors

This table reports the summary statistics of the investor net flows. Panel A focuses on the aggregate investment changes over the entire sample. Net flow is the value of stocks purchased minus the value of stocks sold evaluated at the actual trading price, accumulated over all investors during the specified period. The active net flow is the value of stocks purchased minus the value of stocks sold evaluated at the beginning-of-period price, accumulated over all investors during the specified period. The proportional net flow is the active net flow divided by the beginning-of-period portfolio value, if the active net flow is negative; it is the active net flow divided by the sum of the beginning-of-period portfolio value and the active net flow, if the active net flow is positive. Panel B calculates the three measures for each investor over each month and reports the average of investment changes over different sample periods.

Panel A: Summary statistics for net flows of aggregate individual investors (10 million RMB)

\begin{tabular}{ccccc}
\hline Period & \# Months & Net flow & Active net flow & Proportional net flow (\%) \\
\hline Overall & 47 & -10.13 & -5.43 & 4.80 \\
Pre crisis & 34 & -32.46 & -8.30 & -12.03 \\
Normal market & 20 & 6.14 & 8.34 & 9.97 \\
Bull market & 14 & -38.60 & -17.44 & -21.14 \\
Crisis & 13 & 22.35 & 33.10 & 16.83 \\
1st half of Crisis & 6 & 20.32 & 25.04 & 13.17 \\
2nd half of Crisis & 7 & 2.03 & 5.95 & 3.66 \\
Crisis month & & & & \\
Nov 2007 & & 5.05 & 5.46 & 2.78 \\
Dec 2007 & & 1.99 & 2.32 & 1.32 \\
Jan 2008 & & 2.28 & 3.67 & 1.79 \\
Feb 2008 & & 1.17 & 1.60 & 0.88 \\
Mar 2008 & & 6.21 & 7.28 & 3.67 \\
Apr 2008 & & 3.62 & 4.44 & 2.73 \\
May 2008 & & 1.35 & 1.84 & 1.18 \\
Jun 2008 & & 0.06 & 0.30 & 0.22 \\
Jul 2008 & & 1.57 & 1.60 & 1.51 \\
Aug 2008 & -0.82 & -0.50 & -0.46 \\
Sep 2008 & & -0.30 & 0.15 & 0.17 \\
Oct 2008 & 1.07 & 1.85 & 2.22 \\
Nov 2008 & & -0.90 & -0.72 & -1.18 \\
\hline
\end{tabular}


Panel B: Summary statistics for the net flows at individual investor-month level (10 thousand RMB)

\begin{tabular}{ccccc}
\hline \multicolumn{1}{c}{ Period } & \# Obs. & Net flow & Active net flow & Proportional net flow (\%) \\
\hline Overall & 162267 & 0.62 & 0.39 & -0.15 \\
Pre crisis & 115500 & -2.81 & -1.99 & $-1.28 * * *$ \\
Normal market & 42626 & 1.44 & 1.82 & $-1.37 * * *$ \\
Bull market & 72874 & -5.30 & -4.22 & $-1.22 * * *$ \\
Crisis & 46767 & 4.76 & 6.26 & $2.63 * * *$ \\
1st half of Crisis & 27010 & 7.52 & 9.17 & $3.67 * * *$ \\
2nd half of Crisis & 19757 & 1.02 & 2.29 & $1.20 * * *$ \\
Crisis month & & & & \\
Nov 2007 & 4334 & 11.65 & 12.60 & $4.13 * * *$ \\
Dec 2007 & 4591 & 4.33 & 5.05 & -0.14 \\
Jan 2008 & 5568 & 4.09 & 6.59 & $4.76 * * *$ \\
Feb 2008 & 4012 & 2.91 & 3.99 & $1.24 * *$ \\
Mar 2008 & 4623 & 13.44 & 15.74 & $8.40 * * *$ \\
Apr 2008 & 3882 & 9.33 & 11.44 & $2.97 * * *$ \\
May 2008 & 3831 & 3.51 & 4.81 & $1.85 * * *$ \\
Jun 2008 & 3213 & 0.20 & 0.94 & $2.62 * * *$ \\
Jul 2008 & 3103 & 5.04 & 5.15 & $2.26 * *$ \\
Aug 2008 & 2632 & -3.13 & -1.91 & 0.53 \\
Sep 2008 & 2530 & -1.17 & 0.60 & -0.63 \\
Oct 2008 & 2293 & 4.68 & 8.08 & $5.75 * * *$ \\
Nov 2008 & 2155 & -4.18 & -3.36 & $-5.49 * * *$ \\
\hline
\end{tabular}

** and *** denote statistical significance at the 5 and 1 percent level (two tailed), respectively. 
Table 3: Analysis of Proportional Net Flow at the Individual Investor-Month Level

This table analyzes the proportional net flows based on the following linear regression model:

$$
\text { Proportional net flow }_{i t}=\text { Crisis }_{t}+\text { Crisis }_{t} \times X_{i t}+X_{i t}+\varepsilon_{i t}
$$

where Proportional net flowit measures the active investment changes of individual $i$ at month $t$; Crisis $t_{t}$ is a dummy variable that takes on the value of one during the crisis and zero otherwise; $X_{i t}$ is the vector of potential determinants of investment changes for individual $i$ at month $t$; it consists of the following variables: Positive past return ${ }_{i t}$ and Negative past return ${ }_{i t}$ are the value weighted portfolio returns of individual $i$ at month $t-1$, partitioned into positive and negative observations. Past volatility ${ }_{i t}$ is the standard deviation of the value weighted portfolio of returns over the previous 12 months ending in month $t$ 1. Investment size dummy ${ }_{i}$, Age dummy $i$ and Gender $r_{i}$ are three dummy variables for investment size, age, and gender, taking on the value of one for investors whose investment size is above the median, investors whose age is above the median and female investors, respectively; the variables are set to zero otherwise. Past portfolio turnover it and Number of stocksit represent the monthly portfolio turnover of individual $i$ at month $t-1$ and the beginning-of-month number of stocks in the portfolio of individual $i$ at month $t$, respectively.

Four regressions are estimated using standard errors clustered both by individual level and by time. Column (1) shows the results using observations from the entire sample period. Column (2) excludes observations from the bull market period. Column (3) is based on the pre-crisis period and the first half of the crisis period. Column (4) is based on the pre-crisis period and the second half of the crisis period. *, **, and *** denote statistical significance at the 10, 5 and 1 percent level (two tailed), respectively. 


\begin{tabular}{|c|c|c|c|c|}
\hline & \multicolumn{4}{|c|}{ Dependent variable: Proportional net flow } \\
\hline & (1) & (2) & $(3)$ & (4) \\
\hline Crisis dummy & $\begin{array}{l}0.112 * * * \\
(4.47)\end{array}$ & $\begin{array}{l}0.0700 * * \\
(2.53)\end{array}$ & $\begin{array}{l}0.102 * * * \\
(3.62)\end{array}$ & $\begin{array}{l}0.131 * * * \\
(3.47)\end{array}$ \\
\hline \multicolumn{5}{|l|}{ Crisis dummy $x$} \\
\hline _Positive past return & $\begin{array}{l}-0.235 * * * \\
(-3.48)\end{array}$ & $\begin{array}{l}-0.190 * \\
(-1.80)\end{array}$ & $\begin{array}{l}-0.174 * * * \\
(-3.04)\end{array}$ & $\begin{array}{l}-0.347 * * * \\
(-5.05)\end{array}$ \\
\hline _Negative past return & $\begin{array}{l}0.0134 \\
(0.15)\end{array}$ & $\begin{array}{l}0.00216 \\
(0.02)\end{array}$ & $\begin{array}{l}-0.0687 \\
(-0.71)\end{array}$ & $\begin{array}{l}0.00320 \\
(0.03)\end{array}$ \\
\hline _Past volatility & $\begin{array}{l}-0.0826 \\
(-0.91)\end{array}$ & $\begin{array}{l}0.192 \\
(1.56)\end{array}$ & $\begin{array}{l}-0.0515 \\
(-0.44)\end{array}$ & $\begin{array}{l}-0.222 * \\
(-1.80)\end{array}$ \\
\hline _Investment size dummy & $\begin{array}{l}-0.0844 * * * \\
(-5.69)\end{array}$ & $\begin{array}{l}-0.0737 * * * \\
(-5.39)\end{array}$ & $\begin{array}{l}-0.0664 * * * \\
(-3.68)\end{array}$ & $\begin{array}{l}-0.106 * * * \\
(-6.83)\end{array}$ \\
\hline _Age dummy & $\begin{array}{l}0.0212 * * * \\
(3.21)\end{array}$ & $\begin{array}{l}0.0202 * * * \\
(2.64)\end{array}$ & $\begin{array}{l}0.0224 * * * \\
(3.04)\end{array}$ & $\begin{array}{l}0.0202 * * \\
(2.08)\end{array}$ \\
\hline _Gender & $\begin{array}{l}0.00306 \\
(0.67)\end{array}$ & $\begin{array}{l}0.00746 \\
(1.41)\end{array}$ & $\begin{array}{l}0.00157 \\
(0.29)\end{array}$ & $\begin{array}{l}0.00338 \\
(0.62)\end{array}$ \\
\hline _Past portfolio turnover & $\begin{array}{l}-0.118 * * * \\
(-3.19)\end{array}$ & $\begin{array}{l}-0.0962 * * \\
(-2.53)\end{array}$ & $\begin{array}{l}-0.0651 * \\
(-1.91)\end{array}$ & $\begin{array}{l}-0.176 * * * \\
(-3.36)\end{array}$ \\
\hline _Number of stocks & $\begin{array}{l}-0.000777 \\
(-1.16)\end{array}$ & $\begin{array}{l}-0.00102 \\
(-1.63)\end{array}$ & $\begin{array}{l}-0.00212 * * * \\
(-3.49)\end{array}$ & $\begin{array}{l}0.000479 \\
(0.60)\end{array}$ \\
\hline Positive past return & $\begin{array}{l}-0.127 * * * \\
(-3.51)\end{array}$ & $\begin{array}{l}-0.172 * \\
(-1.95)\end{array}$ & $\begin{array}{l}-0.127 * * * \\
(-3.50)\end{array}$ & $\begin{array}{l}-0.127 * * * \\
(-3.50)\end{array}$ \\
\hline Negative past return & $\begin{array}{l}-0.00804 \\
(-0.12)\end{array}$ & $\begin{array}{l}0.00315 \\
(0.03)\end{array}$ & $\begin{array}{l}-0.00804 \\
(-0.12)\end{array}$ & $\begin{array}{l}-0.00804 \\
(-0.12)\end{array}$ \\
\hline Past volatility & $\begin{array}{l}0.0200 \\
(0.31)\end{array}$ & $\begin{array}{l}-0.254 * * \\
(-2.43)\end{array}$ & $\begin{array}{l}0.0200 \\
(0.31)\end{array}$ & $\begin{array}{l}0.0200 \\
(0.31)\end{array}$ \\
\hline Investment size dummy & $\begin{array}{l}0.0861 * * * \\
(10.00)\end{array}$ & $\begin{array}{l}0.0754 * * * \\
(12.07)\end{array}$ & $\begin{array}{l}0.0861 * * * \\
(9.98)\end{array}$ & $\begin{array}{l}0.0861 * * * \\
(9.98)\end{array}$ \\
\hline Age dummy & $\begin{array}{l}-0.00931 * * \\
(-2.36)\end{array}$ & $\begin{array}{l}-0.00836 \\
(-1.53)\end{array}$ & $\begin{array}{l}-0.00931 * * \\
(-2.35)\end{array}$ & $\begin{array}{l}-0.00931 * * \\
(-2.35)\end{array}$ \\
\hline Gender & $\begin{array}{l}0.00665 * * * \\
(2.91)\end{array}$ & $\begin{array}{l}0.00224 \\
(0.65)\end{array}$ & $\begin{array}{l}0.00665 * * * \\
(2.90)\end{array}$ & $\begin{array}{l}0.00665 * * * \\
(2.90)\end{array}$ \\
\hline Past portfolio turnover & $\begin{array}{l}-0.0634 * * * \\
(-2.85)\end{array}$ & $\begin{array}{l}-0.0855 * * * \\
(-3.57)\end{array}$ & $\begin{array}{l}-0.0634 * * * \\
(-2.84)\end{array}$ & $\begin{array}{l}-0.0634 * * * \\
(-2.84)\end{array}$ \\
\hline Number of stocks & $\begin{array}{l}0.0000271 \\
(0.09)\end{array}$ & $\begin{array}{l}0.000273 \\
(1.53)\end{array}$ & $\begin{array}{l}0.0000271 \\
(0.09)\end{array}$ & $\begin{array}{l}0.0000271 \\
(0.09)\end{array}$ \\
\hline Constant & $\begin{array}{l}-0.0907 * * * \\
(-7.92)\end{array}$ & $\begin{array}{l}-0.0483 * * * \\
(-3.03)\end{array}$ & $\begin{array}{l}-0.0907 * * * \\
(-7.90)\end{array}$ & $\begin{array}{l}-0.0907 * * * \\
(-7.90)\end{array}$ \\
\hline Number of observations & 154451 & 85472 & 135891 & 128790 \\
\hline Adjusted $\mathrm{R}^{2}$ & 0.015 & 0.015 & 0.015 & 0.014 \\
\hline
\end{tabular}


Table 4: Disposition Effect over Different Sample Periods

This table estimates the disposition effect over different sample periods. Panel A shows the results on the investor-month level. In each month, realized gains is the value of stocks sold at higher prices than their average purchase prices, and realized losses is the value of stocks sold at lower prices than their average purchase prices. Paper gains is the value of stocks in the portfolio with higher end-of-month prices than their average purchase prices, and paper losses is the value of stocks with lower end-of-month prices than their average purchase prices. Realized gains, realized losses, paper gains and paper losses are calculated monthly for each investor. The two ratios are then calculated as follows:

$$
\begin{aligned}
& \frac{\text { Realized Gains }}{\text { Realized Gains + Paper Gains }}=\text { Proportion of Gains Realized (PGR) } \\
& \frac{\text { Realized Losses }}{\text { Realized Losses + Paper Losses }}=\text { Proportion of Losses Realized (PLR) }
\end{aligned}
$$

Testing the disposition effect is equivalent to testing $P L G>P L R$.

Panel B reports the average disposition effect on the investor level. We define the disposition effect of individual investor $i$ as:

$$
\text { Disposition Effect }{ }_{i}=\frac{1}{T} \sum_{t=1}^{T}\left(P G R_{i t}-P L R_{i t}\right)
$$

where $T$ represents the total number of months during a given period, $P G R_{i t}$ and $P L R_{i t}$ are calculated as above using realized gains, realized losses, paper gains, paper losses of individual investor $i$ at month $t$.

Panel A: Differences on the investor-month level

\begin{tabular}{lcccc}
\hline & Entire sample & Pre-crisis & Crisis & $\begin{array}{c}\text { Difference } \\
\text { (crisis - pre-crisis) }\end{array}$ \\
\hline Number of realized gains & 86,462 & 61,900 & 24,562 & \\
Number of realized losses & 51,160 & 32,683 & 18,477 & \\
PGR & 0.226 & 0.235 & 0.205 & $-0.030 * * *$ \\
PLR & 0.173 & 0.196 & 0.131 & $-0.066 * * *$ \\
Difference in proportions & $0.054 * * *$ & $0.038 * * *$ & $0.074 * * *$ & \\
\hline \multicolumn{5}{c}{} \\
Panel B: Disposition effect on the investor level & & & \\
& & & & Difference \\
& Entire sample & Pre-crisis & Crisis & (crisis - pre-crisis) \\
\hline Number of obs. & 9,013 & 9,013 & 9,013 & \\
Disposition effect & $0.097 * * *$ & $0.074 * * *$ & $0.099 * * *$ & $0.026 * * *$ \\
Disposition of small investors & $0.109 * * *$ & $0.097 * * *$ & $0.121 * * *$ & $0.024 * * *$ \\
Disposition of large investors & $0.070 * * *$ & $0.056 * * *$ & $0.084 * * *$ & $0.028 * * *$ \\
Difference (small - large) & $0.039 * * *$ & $0.041 * * *$ & $0.038 * * *$ & \\
\hline
\end{tabular}

*** denotes statistical significance at the 1 percent level (two tailed). 
Table 5: Analysis of Relative Portfolio Volatility at the Individual Investor-Month Level

This table analyzes the proportional net flows based on the following linear regression model:

$$
\text { Relative Portfolio Volatility }_{i t}=\text { Crisis }_{t}+\text { Crisis }_{t} \times X_{i t}+X_{i t}+\varepsilon_{i t}
$$

where Relative Portfolio Volatilityit measures the portfolio risk of individual $i$ at month $t$; Crisis $t_{t}$ is a dummy variable that takes on the value of one during the crisis and zero otherwise; $X_{i t}$ is the vector of potential determinants of investment changes for individual $i$ at month $t$; it consists of the following variables: Positive past return ${ }_{i t}$ and Negative past return $_{i t}$ are the value weighted portfolio returns of individual $i$ at month $t-1$, partitioned into positive and negative observations. Investment size dummy, Age dummy and Gender $r_{i}$ are three dummy variables for investment size, age, and gender, taking on the value of one for investors whose investment size is above the median, investors whose age is above the median and female investors, respectively; the variables are set to zero otherwise. Past portfolio turnover it and Number of stocksit represent the monthly portfolio turnover of individual $i$ at month $t-1$ and the beginning-of-month number of stocks in the portfolio of individual $i$ at month $t$, respectively.

Five regressions are estimated using standard errors clustered both by individual level and by time. Column (1) show the results using the entire sample period. Column (2) excludes observations from the bull market period. Column (3) is based on the pre-crisis period and the first half of the crisis period. Column (4) is based on the pre-crisis period and the second half of the crisis period. $*, * *$, and $* * *$ denote statistical significance at the 10, 5 and 1 percent level (two tailed), respectively. 


\begin{tabular}{|c|c|c|c|c|}
\hline & \multicolumn{4}{|c|}{ Dependent variable: Relative portfolio volatility } \\
\hline & $(1)$ & $(2)$ & (3) & $(4)$ \\
\hline Crisis dummy & $\begin{array}{l}-0.299 * * * \\
(-6.07)\end{array}$ & $\begin{array}{l}-0.260 * * * \\
(-4.90)\end{array}$ & $\begin{array}{l}-0.266 * * * \\
(-4.64)\end{array}$ & $\begin{array}{l}-0.359 * * * \\
(-6.27)\end{array}$ \\
\hline \multicolumn{5}{|l|}{ Crisis dummy $\times$} \\
\hline _Positive past return & $\begin{array}{l}-0.253 \\
(-0.85)\end{array}$ & $\begin{array}{l}-0.707 * * \\
(-2.54)\end{array}$ & $\begin{array}{l}-0.188 \\
(-0.64)\end{array}$ & $\begin{array}{l}-0.404 \\
(-1.39)\end{array}$ \\
\hline _Negative past return & $\begin{array}{l}1.482 * * * \\
(3.12)\end{array}$ & $\begin{array}{l}1.401 * * * \\
(3.58)\end{array}$ & $\begin{array}{l}1.352 * * * \\
(2.61)\end{array}$ & $\begin{array}{l}1.506 * * * \\
(3.07)\end{array}$ \\
\hline _Investment size dummy & $\begin{array}{l}0.0463 * * * \\
(3.08)\end{array}$ & $\begin{array}{l}0.0389 * * \\
(2.23)\end{array}$ & $\begin{array}{l}0.0293 * \\
(1.66)\end{array}$ & $\begin{array}{l}0.0735 * * * \\
(5.60)\end{array}$ \\
\hline _Age dummy & $\begin{array}{l}-0.00262 \\
(-0.26)\end{array}$ & $\begin{array}{l}0.0102 \\
(0.87)\end{array}$ & $\begin{array}{l}0.00317 \\
(0.27)\end{array}$ & $\begin{array}{l}-0.00905 \\
(-0.83)\end{array}$ \\
\hline _Gender & $\begin{array}{l}0.00785 \\
(0.81)\end{array}$ & $\begin{array}{l}0.00616 \\
(0.54)\end{array}$ & $\begin{array}{l}0.000115 \\
(0.01)\end{array}$ & $\begin{array}{l}0.0173 \\
(1.47)\end{array}$ \\
\hline _Past portfolio turnover & $\begin{array}{l}-0.0426 \\
(-0.66)\end{array}$ & $\begin{array}{l}-0.248 * * * \\
(-3.79)\end{array}$ & $\begin{array}{l}-0.146 * * \\
(-2.38)\end{array}$ & $\begin{array}{l}0.0966 \\
(1.49)\end{array}$ \\
\hline _Number of stocks & $\begin{array}{l}0.00862 * * * \\
(5.70)\end{array}$ & $\begin{array}{l}0.00490 * * \\
(2.52)\end{array}$ & $\begin{array}{l}0.00835 * * * \\
(4.88)\end{array}$ & $\begin{array}{l}0.00898 * * * \\
(5.89)\end{array}$ \\
\hline Positive past return & $\begin{array}{l}1.564 * * * \\
(6.54)\end{array}$ & $\begin{array}{l}2.018 * * * \\
(9.59)\end{array}$ & $\begin{array}{l}1.564 * * * \\
(6.53)\end{array}$ & $\begin{array}{l}1.564 * * * \\
(6.53)\end{array}$ \\
\hline Negative past return & $\begin{array}{l}-2.249 * * * \\
(-5.07)\end{array}$ & $\begin{array}{l}-2.168 * * * \\
(-6.15)\end{array}$ & $\begin{array}{l}-2.249 * * * \\
(-5.06)\end{array}$ & $\begin{array}{l}-2.249 * * * \\
(-5.06)\end{array}$ \\
\hline Investment size dummy & $\begin{array}{l}-0.0454 * * * \\
(-5.00)\end{array}$ & $\begin{array}{l}-0.0380 * * * \\
(-3.29)\end{array}$ & $\begin{array}{l}-0.0454 * * * \\
(-5.00)\end{array}$ & $\begin{array}{l}-0.0454 * * * \\
(-5.00)\end{array}$ \\
\hline Age dummy & $\begin{array}{l}-0.0182 * * \\
(-2.51)\end{array}$ & $\begin{array}{l}-0.0310 * * * \\
(-3.60)\end{array}$ & $\begin{array}{l}-0.0182 * * \\
(-2.51)\end{array}$ & $\begin{array}{l}-0.0182 * * \\
(-2.51)\end{array}$ \\
\hline Gender & $\begin{array}{l}-0.0200 * * * \\
(-2.73)\end{array}$ & $\begin{array}{l}-0.0183 * * \\
(-2.08)\end{array}$ & $\begin{array}{l}-0.0200 * * * \\
(-2.73)\end{array}$ & $\begin{array}{l}-0.0200 * * * \\
(-2.73)\end{array}$ \\
\hline Past portfolio turnover & $\begin{array}{l}0.237 * * * \\
(5.29)\end{array}$ & $\begin{array}{l}0.442 * * * \\
(9.82)\end{array}$ & $\begin{array}{l}0.237 * * * \\
(5.28)\end{array}$ & $\begin{array}{l}0.237 * * * \\
(5.28)\end{array}$ \\
\hline Number of stocks & $\begin{array}{l}-0.0238 * * * \\
(-12.35)\end{array}$ & $\begin{array}{l}-0.0201 * * * \\
(-11.25)\end{array}$ & $\begin{array}{l}-0.0238 * * * \\
(-12.34)\end{array}$ & $\begin{array}{l}-0.0238 * * * \\
(-12.34)\end{array}$ \\
\hline Constant & $\begin{array}{l}1.533 * * * \\
(52.21)\end{array}$ & $\begin{array}{l}1.494 * * * \\
(43.12)\end{array}$ & $\begin{array}{l}1.533 * * * \\
(52.11)\end{array}$ & $\begin{array}{l}1.533 * * * \\
(52.13)\end{array}$ \\
\hline Number of observations & 154451 & 85472 & 135891 & 128790 \\
\hline Adjusted $\mathrm{R}^{2}$ & 0.209 & 0.184 & 0.202 & 0.209 \\
\hline
\end{tabular}


Table 6: Portfolio characteristics of individual investors

This table reports investor portfolio characteristics using five measures. Size $e_{j}$ is the average monthly market capitalization of stock $j$ during the sample period; Volatility $y_{j}$ is the standard deviation of monthly returns of stock $j$; Excess volatility Ex $_{j}$ the standard deviation of the monthly excess returns of stock $j$, and the monthly excess return is the difference between the stock return and market return; Government ownership $p_{j}$ is the average percentage of shares owned by government during our sample period; Illiquidity ${ }_{j}$ is the average ratio of the absolute value of monthly returns to volume of stock $j$ during our sample period. We first partition the stocks into deciles based on the above measures in ascending order. These five characteristics are sorted independently. Define $g_{j}(=1, \ldots, 10)$ as the rank of the characteristic group containing stock $j$. Panel A summarizes the average of stock characteristics.

Panel B reports the results of individual portfolio characteristics in the pre-crisis and crisis periods. The monthly value weighted Individual Portfolio Characteristics (IPC $\left.C_{i t}\right)$ are calculated as follows:

$$
I P C_{i t}=\frac{\sum_{j=1}^{N_{i t}} \text { Value of } \text { stocks }_{i, j, t} \times g_{j}}{\text { Value of portfolio }{ }_{i, t}}
$$

where $N_{i t}$ is the number of total stocks held by individual $i$ at time $t$, Value of portfolioit is the beginning-of-month portfolio value of individual $i$ at time $t$, Value of stocks $s_{i, j, t}$ is the value of stock $j$ held in the beginning-of-month portfolio of individual $i$ at time $t$.

Panel $\mathrm{C}$ reports the results of calendar-time portfolios. The monthly value-weighted Calendar-time Portfolio Characteristics $\left(C P C_{t}\right)$ are calculated as follows:

$$
C P C_{i t}=\frac{\sum_{j=1}^{N_{t}} \text { Value of }_{\text {stocks }} \times g_{j, t}}{\text { Value of calendar-time portfolio }}
$$

where $N_{t}$ is the total number of stocks held by all investors at time $t$, Value of stocks $s_{j, t}$ is the value of stock $j$ held by all the individual investors at the beginning of month $t$, Value of calendar-time portfolio $t_{\text {is }}$ the sum of Value of stocksj,t over all stocks at time $t$. *, **, and $* * *$ denote statistical significance at the 10, 5 and 1 percent level (two tailed), respectively. 
Panel A: The average of stock characteristics based on 10 groups

\begin{tabular}{lcccccccccc}
\hline & \multicolumn{1}{c}{ Group rank } \\
\cline { 2 - 11 } & $(1)$ & $(2)$ & $(3)$ & $(4)$ & $(5)$ & $(6)$ & $(7)$ & $(8)$ & $(9)$ & $(10)$ \\
\hline Number of obs. & 164 & 164 & 164 & 163 & 164 & 164 & 163 & 164 & 164 & 164 \\
Size (1 billion RMB) & 0.65 & 1.07 & 1.36 & 1.68 & 2.05 & 2.60 & 3.36 & 4.74 & 8.22 & 116.0 \\
Volatility & 0.11 & 0.15 & 0.16 & 0.17 & 0.18 & 0.19 & 0.20 & 0.21 & 0.23 & 0.40 \\
Excess volatility & 0.10 & 0.12 & 0.13 & 0.14 & 0.15 & 0.16 & 0.16 & 0.18 & 0.19 & 0.37 \\
Government ownership & 0.31 & 0.42 & 0.48 & 0.52 & 0.55 & 0.59 & 0.63 & 0.69 & 0.74 & 0.84 \\
Illiquidity (1/1 billion) & 0.02 & 0.05 & 0.08 & 0.11 & 0.14 & 0.17 & 0.21 & 0.26 & 0.35 & 1.02 \\
\hline
\end{tabular}

Panel B: Portfolio characteristics of individual portfolios

\begin{tabular}{|c|c|c|c|c|c|c|}
\hline & \multirow[b]{2}{*}{ Entire sample } & \multirow[b]{2}{*}{ Pre-crisis } & \multirow[b]{2}{*}{ Crisis } & \multicolumn{3}{|c|}{ Changes (crisis - pre-crisis) } \\
\hline & & & & All investors & Small investors & Large investors \\
\hline Number of obs. & 408,091 & 309,910 & 98,181 & & 176345 & 231746 \\
\hline Size & 7.159 & 7.091 & 7.370 & $0.279 * * *$ & $0.362 * * *$ & $0.194 * * *$ \\
\hline Volatility & 5.039 & 5.103 & 4.836 & $-0.267 * * *$ & $-0.462 * * *$ & $-0.137 * * *$ \\
\hline Excess volatility & 4.727 & 4.803 & 4.490 & $-0.312 * * *$ & $-0.471 * * *$ & $-0.201 * * *$ \\
\hline Government ownership & 4.935 & 4.799 & 5.365 & $0.565 * * *$ & $0.742 * * *$ & $0.424 * * *$ \\
\hline Illiquidity & 3.793 & 3.863 & 3.571 & $-0.292 * * *$ & $-0.431 * * *$ & $-0.170 * * *$ \\
\hline
\end{tabular}

Panel C: Characteristics of calendar-time portfolios

\begin{tabular}{|c|c|c|c|c|c|c|}
\hline & \multirow[b]{2}{*}{ Entire sample } & \multirow[b]{2}{*}{ Pre-crisis } & \multirow[b]{2}{*}{ Crisis } & \multicolumn{3}{|c|}{ Changes (crisis - pre-crisis) } \\
\hline & & & & All investors & Small investors & Large investors \\
\hline Number of obs. & 47 & 34 & 13 & & 47 & 47 \\
\hline Size & 7.298 & 7.276 & 7.354 & $0.0776 * *$ & $0.363 * * *$ & 0.0512 \\
\hline Volatility & 4.972 & 5.008 & 4.876 & $-0.132 * * *$ & $-0.555 * * *$ & $-0.102 * * *$ \\
\hline Excess volatility & 4.676 & 4.726 & 4.546 & $-0.181 * * *$ & $-0.541 * * *$ & $-0.155 * * *$ \\
\hline Government ownership & 5.147 & 5.085 & 5.308 & $0.223 * * *$ & $0.715 * * *$ & $0.182 * * *$ \\
\hline Illiquidity & 3.713 & 3.747 & 3.626 & $-0.121 * * *$ & $-0.463 * * *$ & $-0.0928 * * *$ \\
\hline
\end{tabular}

